\title{
RESULTS OF RADIOCARBON ANALYSIS OF UPPER WEICHSELIAN LOESS SEQUENCES FROM HUNGARY
}

\author{
Pál Sümegi ${ }^{1,2} \bullet$ Mihály Molnár $^{3}$ • Éva Svingor ${ }^{3}$ - Zsuzsanna Szántó ${ }^{*}$ László Hum $^{1} \bullet$ \\ Sándor Gulyás ${ }^{1}$
}

\begin{abstract}
Approximately $10 \%$ of Hungary is covered by dust sequences of the Quaternary period. Samples have been taken from more than 50 outcrops and boreholes during fieldwork in the past $20 \mathrm{yr}$. Some 81 bulk samples taken from 27 profiles of the Hungarian loess regions have been analyzed for radiocarbon. Based on the ${ }^{14} \mathrm{C}$ results, loess layers that accumulated between 33,000 and 12,000 BP were selected for further investigation. The sedimentation rates of the 27 loess profiles suggest periods of slow and quick dust accumulation in the Carpathian Basin during the Upper Weichselian period. It seems to us that some soil development and intense weathering periods interrupted the loess development during the Upper Weichselian in Hungary. According to the ${ }^{14} \mathrm{C}$ dates, the estimated average rate of sedimentation was $0.31 \mathrm{~mm} / \mathrm{yr}$ in both the northern and southern parts of the Carpathian Basin between 33,000 and 12,000 BP.
\end{abstract}

\section{INTRODUCTION}

Loess deposits cover a region of about 13 million $\mathrm{km}^{2}$ on Earth, about $10 \%$ of the total area of the continents (Pécsi 1993). Approximately $10 \%$ of Hungary is covered by these dust sequences (Pécsi 1967). This sediment type is one of the most characteristic and extensive for the Quaternary, the formation of which is exclusively restricted to the Pleistocene, mainly its younger periods. According to the available information, the occurrence and formation of loess is also related to certain geographical belts or areas (North American, Eurasian, and South American loess areas) and to environmental factors.

The most remarkable fossils embedded in the loess sequences are mollusk shells, quite often accumulated in large masses. The geochemical conditions prevailing during the formation and diagenesis of these dust deposits were ideal for preserving calcareous shells (Krolopp 1961, 1966, 1967; Ložek 1964; Rousseau et al. 1990). The study of mollusk remains, the so-called "loess fauna," was of primary importance in the extensive Quaternary investigations at the beginning of the 20th century in Hungary (Horusitzky 1903; Rotarides 1931, 1942; Horváth 1954; Krolopp 1961, 1966). The representatives of the mollusk fauna retrieved from the loess deposits are important not only because of their large mass, but also because they are made up of predominantly modern forms in addition to the extinct ones, with known ecological characters, requirements, distribution, and tolerance to particular environmental factors such as temperature, humidity, vegetation cover, etc. Thus, acting as indicators of the ancient paleoecological conditions, the environmental components of loess formation can be relatively well assessed.

The Quaternary mollusk faunas are dominantly represented by recent elements (Krolopp 1967, 1984); thus, the ecological requirements of the modern taxa (Boycott 1934; Soós 1943; Ant 1963; Kerney et al. 1983) as well as their use in Pleistocene environmental interpretations (Rotarides 1931; Ložek 1964; Krolopp 1967; Rousseau et al. 1990) are relatively well established. As a consequence, the study of loess fauna has become one of the most important and fundamental assets in investigations of dust sequences. This is especially true for studies of Paleolithic (mainly Upper Paleolithic)

\footnotetext{
'University of Szeged, Department of Geology and Paleontology, 6722 Szeged, Egyetem u. 2-6, Hungary.

${ }^{2}$ Corresponding author. Email: sumegi@ geo.u-szeged.hu.

${ }^{3}$ Institute of Nuclear Research of Hungarian Academy of Sciences, Laboratory of Environmental Studies, 4026 Debrecen Bem tér 18/C, Hungary.
} 
sites discovered from the loess sequences. In contrast to the vertebrate remains recovered from these sequences, the representatives of the tiny mollusk fauna, predominantly of $\mathrm{mm}$ size, were not subjected to selection attributed to human gathering and hunting. The investigation of the mollusk fauna enables the reconstruction of the prevailing conditions of areas surrounding settlement sites. Furthermore, one may also determine the various climatic and environmental changes - which occurred during, preceding, and following the construction of the settlement-by studying underlying and overlying sediments. Finally, a comparative analysis of several distinct profiles contributes to the reconstruction of the larger, more distant areas of ancient Paleolithic hunter communities.

Investigations on the loess malacofauna, as well as the evaluation of its paleoecological and paleoclimatological importance in Hungary, started almost coevally with international studies of similar scope in the 1890s. These studies, using different methodological and conceptual approaches, yielded an extensive database on the loess-covered areas, with information mostly related to the youngest, near-surface layers, thus enabling and requiring a comparative synthesis (Krolopp and Sümegi 1992; Sümegi and Krolopp 1996). Not only were fauna subjected to detailed analysis during these investigations, but relying on the financial support of the various National Scientific Research Funds (OTKA), the embedded deposits of the studied profiles also underwent sedimentological, geochemical, and isotope-geochemical analyses from about 1986 onwards, opening up the possibility for a complex paleoecological reconstruction. The most challenging and outstanding part of our work was the investigation of those Hungarian loess profiles, which were also the sites of human settlements and yielded Upper Paleolithic artifacts (Figure 1). The new information forced us to rethink and modify the formerly assigned paleoecological and paleoclimatological indicator roles of the terrestrial mollusk fauna. Furthermore, the intensive Hungarian studies of Quaternary mollusks over the last $20 \mathrm{yr}$ has led to the re-evaluation of the former paleobiogeographical view of the Carpathian Basin for the end of the Quaternary, as well as that of the Upper Würmian vegetation and faunal history, and the final development of a complex climate and ecostratigraphic system based on the synthesis of paleontological data of the Quaternary mollusk fauna with measured radiocarbon dates (Krolopp and Sümegi 1990, 1991, 1992; Sümegi 1996, 1998, 1999, 2004, 2005; Sümegi and Krolopp 1996; Willis et al. 2000; Rudner and Sümegi 2001; Sümegi and Rudner 2001).

\section{MATERIALS AND METHODS}

Samples have been taken from more than 50 outcrops and boreholes during fieldwork over the past $20 \mathrm{yr}$. Some 81 bulk samples taken from 27 profiles of the Hungarian loess regions have been analyzed for ${ }^{14} \mathrm{C}$ (Figure 1). In our work, charcoal remains and mollusk shells retrieved from the profiles have been analyzed using 20-25 g of mollusk shell fragments and 6-10 $\mathrm{g}$ of the charcoal. The methods presented in Hertelendi et al. (1996) have been utilized for the preparation of the mollusk samples. Approximately $200 \mathrm{~kg}$ of sediment was wet-sieved to gain the required quantities of mollusk shells, which were then cleaned by boiling in distilled water and dilute $\mathrm{H}_{2} \mathrm{O}_{2}$. The steps and physical parameters of ${ }^{14} \mathrm{C}$ measurements are discussed at length in the work of Hertelendi et al. (1989).

In order to minimize or eliminate the bias deriving from the presence of inactive carbonates, only herbivorous gastropod shells (Frömming 1954; Grime and Blythe 1969), primarily those of Arianta arbustorum, have been used in our measurements, following the proposal of Preece (1991).

The surficial precipitates were removed by treatment with diluted $\mathrm{H}_{2} \mathrm{O}_{2}$ (Hertelendi et al. 1992). It is important to emphasize that none of the ${ }^{14} \mathrm{C}$ measurements implemented on mollusks and charcoal deriving from Hungarian profiles dated to the end of the Quaternary yielded controversial dates, i.e. younger ages within the deeper parts of the sections. Furthermore, the multiple measurements of 


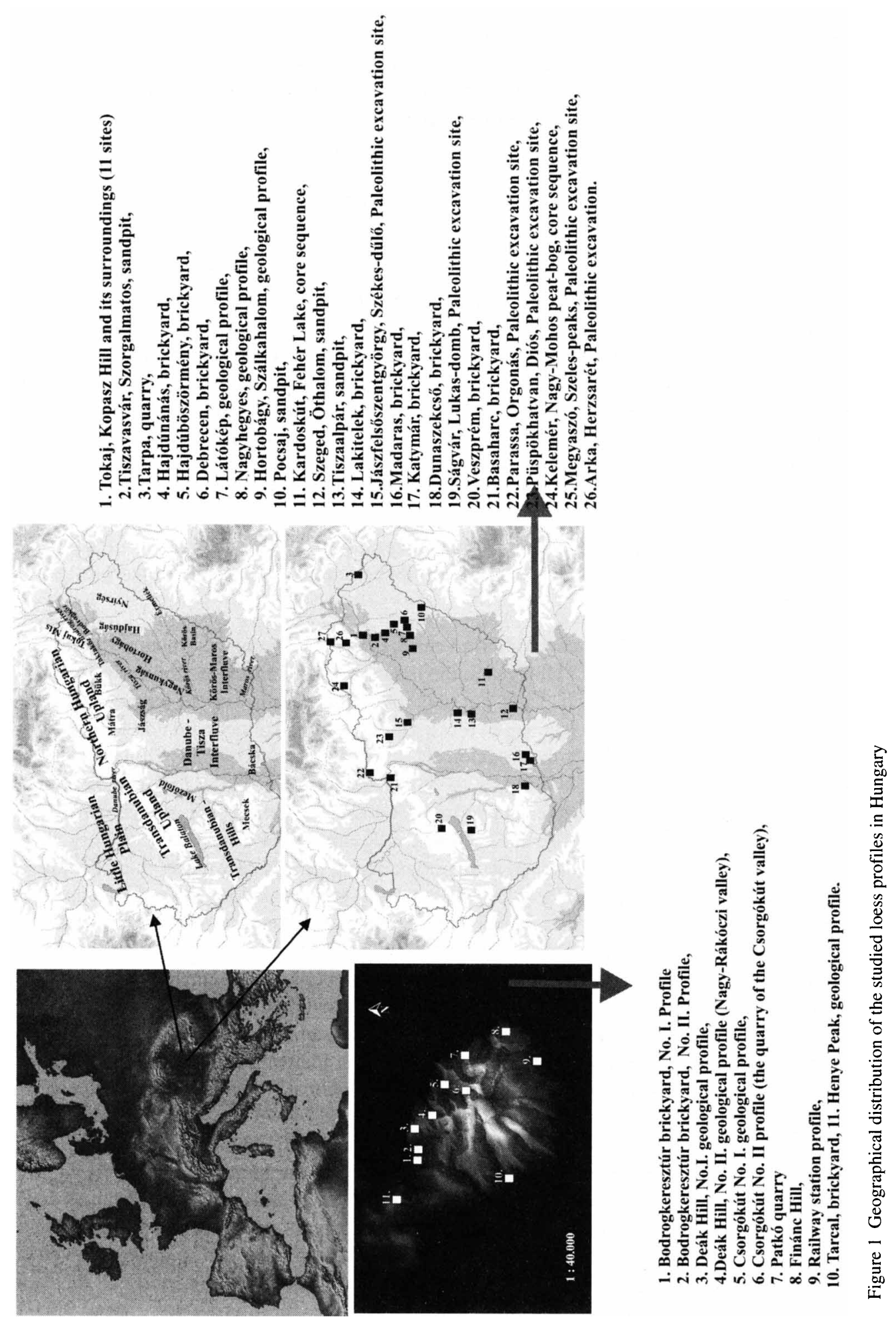


samples deriving from several horizons of individual profiles yielded reliable, acceptable dates after comparison with each other (Sümegi 1989; Hertelendi et al. 1992; Sümegi et al. 1992; Szöór et al. 1992; Krolopp et al. 1995). Consequently, mollusk shells seem to be suitable for ${ }^{14} \mathrm{C}$ measurements and dating horizons within embedded geological profiles or sediments. The resulting dates were calibrated using OxCal v 3.10 (Bronk Ramsey 1995, 2001) and the IntCal04 calibration curve (Reimer et al. 2004).

\section{RESULTS OF RADIOCARBON ANALYSIS}

The ${ }^{14} \mathrm{C}$ results are given in Table 1 . Based on these dates, loess layers that accumulated between 33,000 and 12,000 BP were selected for further investigation. The sedimentation rates of the 27 loess profiles suggest that slow and quick dust accumulation periods must have developed in the Carpathian Basin during the Upper Weichselian. It seems to us that some soil development and intense weathering periods interrupted the loess development time during the Upper Weichselian in Hungary. According to the resulting dates, the estimated average rate of sedimentation was $0.31 \mathrm{~mm} / \mathrm{yr}$ in both the northern and southern parts of the Carpathian Basin between 33,000 and $12,000 \mathrm{BP}$. The determined sedimentation rates were used to give a time frame of the inferred paleoecological changes in the profiles and in the analyzed region, because the sedimentation rate was higher in the southern part of the Carpathian Basin during the Upper Pleniglacial than in its northern counterpart. These sedimentation rate differences suggest that there were 2 sediment accumulation areas in the analyzed regions. The Quarternary malacological data show clearly that different paleoclimatic, vegetation, and soil surface conditions developed in the southern and northern parts of the Carpathian Basin.

All of these data seem to indicate that the inferred changes in the paleotemperatures reflect not only warmings or coolings in general, but changes in the intensity of the different climatic influences in the different parts of the basin as well. Thus, not only the absolute values of the temperature should be taken into account in a paleoenvironmental reconstruction, but also the trend and location of the temperature changes with regard to the position of the different overlapping climate zones. As expected, moving towards the NE in Hungary there is a gradual increase in the continental influences, while the intensity of Mediterranean influences increase towards the southern parts. The expansion of these climate zones is marked by the advent and retreat of different mollusk species and contrasting dust accumulation rates, as well as weathering processes varying regionally during the stadials and interstadials (Sümegi 2005). However, there were considerable spatial and temporal differences in dust accumulation rates in the Carpathian Basin, compared to the average value. Dust accumulation was characterized by a succession of slow and fast sedimentation cycles during the period under study. A highly characteristic soil horizon developed in the sequences between 33,000 and 25,000 yr. As a result of the significant diagenetic transformations, a reddish-brown soil horizon of considerable thickness developed in the northern montane and foothill area of the Carpathian Basin, stretching to the northern parts of the Great Hungarian Plains and northern Transdanubia as well to the west. Conversely, the center of the lowlands of the Great Hungarian Plains witnessed the evolution of immature humic horizons intercalated with wind-blown sands during this time. As shown in previous paleobotanical studies (Rudner and Sümegi 2001; Sümegi and Rudner 2001), a highly complex system of vegetation mosaics developed in the northern parts of the basin at this time, dominated by spruce woodlands containing mixed deciduous and coniferous elements as well as some open areas. Conversely, the vegetation of the southern parts was less compact, composed of Scotch pine and birch woodlands. Significant environmental differences can be observed even during this soil formation period. These differences were preserved in later periods of the Upper Würmian as well as in the Late Glacial. The estimated sedimentation rates were around $0.05-0.1$ 
$\mathrm{mm} / \mathrm{yr}$ in the north, while this value was around $0.1-0.2 \mathrm{~mm} / \mathrm{yr}$ in the south due to the presence of sandy intercalations in the sequences.

Table $1{ }^{14} \mathrm{C}$ dates for the studied loess sites.

\begin{tabular}{|c|c|c|c|c|}
\hline Sites & Depth $(\mathrm{m})$ & Age (yr BP) & Lab code (Deb-) & Sample type \\
\hline Basaharc, brickyard & $4.25-4.5$ & $24,030 \pm 317$ & 3353 & Charcoal \\
\hline Megyaszó, Szeles Hill & - & $27,070 \pm 680$ & 5372 & Charcoal \\
\hline Hont III/Parassa, Orgonás & - & $27,350 \pm 610$ & 5027 & Charcoal \\
\hline Püspökhatvan-Diós, Paleolithic site & $1.5-1.6$ & $27,700 \pm 300$ & 1901 & Charcoal \\
\hline Jászfelsôszentgyörgy, Szúnyogos & $1.3-1.4$ & $18,500 \pm 400$ & 1674 & Bone \\
\hline Jászfelsốszentgyörgy, Székes & $0.7-0.8$ & $11,600 \pm 138$ & 4390 & Shell \\
\hline Jászfelsőszentgyörgy, Székes & $0.5-0.6$ & $7750 \pm 120$ & 4391 & Shell \\
\hline Bodrogkeresztúr, Henye Peaks & $0.5-0.6$ & $26,318 \pm 365$ & 3051 & Charcoal \\
\hline Bodrogkeresztúr brickyard I & $5.0-5.25$ & $26,851 \pm 398$ & 3049 & Charcoal \\
\hline Bodrogkeresztúr brickyard I & $3.25-3.5$ & $19,813 \pm 170$ & 4335 & Shell \\
\hline Bodrogkeresztúri brickyard I & $1.25-1.5$ & $15,388 \pm 147$ & 4358 & Shell \\
\hline Bodrogkeresztúri brickyard II & $3.0-3.25$ & $17,680 \pm 300$ & 1614 & Shell \\
\hline Bodrogkeresztúri brickyard II & $1.5-1.75$ & $14,858 \pm 101$ & 4340 & Shell \\
\hline Bodrogkeresztúri brickyard II & $0.75-1.0$ & $4700 \pm 170$ & 1065 & Shell \\
\hline Tokaj Kereszt Hill II & $4.5-4.75$ & $27,323 \pm 644$ & 2657 & Charcoal \\
\hline Tokaj Kereszt Hill I & $4.75-5.0$ & $26,962 \pm 657$ & 5052 & Charcoal \\
\hline Tokaj Kereszt Hill I & $0.5-0.75$ & $17,619 \pm 170$ & 4918 & Shell \\
\hline Tokaj Kereszt Hill I & $0.25-0.5$ & $783 \pm 35$ & 4874 & Shell \\
\hline Csorgókút I & $4.75-5.0$ & $26,618 \pm 532$ & 3042 & Charcoal \\
\hline Csorgókút I & $0.5-0.75$ & $17,213 \pm 162$ & 2656 & Shell \\
\hline Csorgókút I & $0.5-0.75$ & $16,940 \pm 250$ & 2722 & Shell \\
\hline Csorgókút II & $5.75-6.0$ & $28,225 \pm 360$ & 3035 & Charcoal \\
\hline Csorgókút II & $5.0-5.1$ & $23,571 \pm 486$ & 4350 & Charcoal \\
\hline Csorgókút II & $1.25-1.5$ & $18,730 \pm 180$ & 4330 & Shell \\
\hline Csorgókút II & $0.75-1.0$ & $17,504 \pm 106$ & 4330 & Shell \\
\hline Patkó-quarry & $5.0-5.25$ & $27,491 \pm 362$ & 3043 & Charcoal \\
\hline Patkó-quarry & $4.0-4.25$ & $23,519 \pm 494$ & 4350 & Charcoal \\
\hline Patkó-quarry & $3.0-3.25$ & $18,506 \pm 277$ & 2661 & Shell \\
\hline Patkó-quarry & $2.5-2.75$ & $17,739 \pm 127$ & 4332 & Shell \\
\hline Patkó-quarry & $2.0-2.25$ & $16,322 \pm 162$ & 4364 & Shell \\
\hline Vasúti geological profile & $4.75-5.25$ & $30,174 \pm 1101$ & 4347 & Charcoal \\
\hline Tarcal brickyard & $6.75-7.0$ & $27,251 \pm 288$ & 4345 & Charcoal \\
\hline Tarcal brickyard & $0.25-0.5$ & $5350 \pm 150$ & 1063 & Shell \\
\hline Debrecen Alföldi brickyard & $3.25-3.5$ & $22,800 \pm 300$ & 1561 & Shell \\
\hline Debrecen Alföldi brickyard & $2.5-2.75$ & $18,090 \pm 200$ & 1537 & Shell \\
\hline Debrecen Alföldi brickyard & $2.0-2.25$ & $15,740 \pm 200$ & 1565 & Shell \\
\hline Debrecen Alföldi brickyard & $1.25-1.5$ & $13,380 \pm 200$ & 1547 & Shell \\
\hline Debrecen Alföldi brickyard & $0.75-1.0$ & $10,010 \pm 200$ & 1277 & Shell \\
\hline Debrecen Alföldi brickyard & $0.5-0.75$ & $8750 \pm 200$ & 1091 & Shell \\
\hline Debrecen Alföldi brickyard & $0.25-0.5$ & $7130 \pm 200$ & 1276 & Shell \\
\hline Látóképi geological profile & $3.25-3.5$ & $25,020 \pm 500$ & 1077 & Shell \\
\hline Nagyhegyesi geological profile & $3.75-4.0$ & $25,520 \pm 500$ & 1066 & Shell \\
\hline Nagyhegyesi geological profile & $5.5-6.0$ & $29,810 \pm 300$ & 1596 & Shell \\
\hline Derecskei brickyard & $1.0-1.25$ & $9500 \pm 200$ & 1302 & Shell \\
\hline Pocsaj sandpit & $2.25-2.5$ & $19,600 \pm 200$ & 1582 & Shell \\
\hline Pocsaj sandpit & $5.0-5.25$ & $42,500 \pm 2500$ & 1583 & Shell \\
\hline Lakiteleki brickyard I & $5.8-6.0$ & $29,980 \pm 550$ & 1095 & Charcoal \\
\hline Lakiteleki brickyard I & $3.0-3.2$ & $22,110 \pm 300$ & 1562 & Shell \\
\hline Lakiteleki brickyard I & $2.2-2.4$ & $16,820 \pm 200$ & 1536 & Shell \\
\hline Lakiteleki brickyard I & $1.4-1.6$ & $14,840 \pm 300$ & 1075 & Shell \\
\hline Lakiteleki brickyard I & $0.6-0.8$ & $11,700 \pm 250$ & 1092 & Shell \\
\hline Lakiteleki brickyard II & $2.8-3.2$ & $26,736 \pm 629$ & 4346 & Charcoal \\
\hline
\end{tabular}


Table $1{ }^{14} \mathrm{C}$ dates for the studied loess sites. (Continued)

\begin{tabular}{lccll}
\hline Sites & Depth $(\mathrm{m})$ & Age $(\mathrm{yr}$ BP) & Lab code (Deb-) & Sample type \\
\hline Szeged-Öthalom I & $4.25-4.5$ & $25,200 \pm 300$ & 2049 & Charcoal \\
Szeged-Öthalom I & $2.5-2.75$ & $18,205 \pm 206$ & 3184 & Shell \\
Szeged-Öthalom I & $2.0-2.25$ & $16,323 \pm 145$ & 3159 & Shell \\
Szeged-Öthalom I & $1.75-2.0$ & $16,080 \pm 150$ & 1486 & Shell \\
Szeged-Öthalom I & $1.5-1.75$ & $16,000 \pm 200$ & 2056 & Shell \\
Szeged-Öthalom II & $3.0-3.25$ & $18,080 \pm 200$ & 1600 & Shell \\
Szeged-Öthalom II & $2.5-2.75$ & $16,530 \pm 200$ & 2054 & Shell \\
Szeged-Öthalom II & $1.5-1.75$ & $15,890 \pm 200$ & 2057 & Shell \\
Szeged-Öthalom II & $0.75-1.0$ & $14,179 \pm 140$ & 3183 & Shell \\
Szeged-Öthalom hunted mammoth & $1.5-1.6$ & $15,916 \pm 168$ & 3344 & Bone \\
Katymár brickyard & $9.0-9.25$ & $29,828 \pm 554$ & 3058 & Charcoal \\
Katymár brickyard & $6.0-6.25$ & $23,749 \pm 360$ & 3064 & Charcoal \\
Katymár brickyard & $1.25-1.5$ & $13,944 \pm 93$ & 3253 & Shell \\
Madaras brickyard & $10.0-10.5$ & $21,937 \pm 252$ & 3104 & Charcoal \\
Kardoskút, Fehér-lake & $6.2-6.3$ & $23,303 \pm 280$ & 4572 & Charcoal \\
Kardoskút, Fehér-lake & $4.9-5.1$ & $20,323 \pm 300$ & 7695 & Shell \\
Kardoskút, Fehér-lake & $3.9-4.1$ & $17,715 \pm 250$ & 7694 & Shell \\
Kardoskút, Fehér-lake & $2.1-2.2$ & $10,498 \pm 90$ & 4883 & Shell \\
Kardoskút, Fehér-lake & $1.5-1.6$ & $8239 \pm 70$ & 4910 & Shell \\
Hortobágy, Szálkahalom & $1.9-2.0$ & $19,260 \pm 200$ & 1654 & Shell \\
Hortobágy, Szálkahalom & $1.7-1.8$ & $18,770 \pm 200$ & 1570 & Shell \\
Hortobágy, Szálkahalom & $1.5-1.6$ & $15,800 \pm 200$ & 1546 & Shell \\
Hortobágy, Szálkahalom & $1.2-1.3$ & $13,380 \pm 200$ & 1547 & Shell \\
Hortobágy, Szálkahalom & $0.8-0.9$ & $10,030 \pm 200$ & 1653 & Shell \\
Budapest, Csillaghegy, Paleolithic site & $1.75-2.0$ & $15,935 \pm 142$ & 3160 & Shell \\
Császártöltés, brickyard & $5.0-6.5$ & $31,300 \pm 300$ & 3161 & Shell \\
Susak, loess, section & $7.0-7.25$ & $31,830 \pm 720$ & 6679 & Charcoal \\
Tiszaalpári high-bluff & $3.75-4.0$ & $17,860 \pm 350$ & 1078 & Shell \\
Tiszaalpári high-bluff & $2.5-2.75$ & $15,310 \pm 350$ & 1080 & Shell \\
Tiszaalpári high-bluff & $5.25-5.5$ & $27,810 \pm 210$ & POZ-8622 & Charcoal \\
\hline
\end{tabular}

There was an acceleration of dust accumulation from 25,000 yr onwards in both parts of the basin, yielding values of $0.2-0.4 \mathrm{~mm} / \mathrm{yr}$ in the north and $0.5-0.8 \mathrm{~mm} / \mathrm{yr}$ in the south. It is no wonder that one of the most remarkable European Upper Würmian loess sequences developed in the southern parts of the basin in the Telecska Hills (Molnár and Krolopp 1978; Molnár and Geiger 1995). The observed differences in the dust accumulation rates must be attributed to both differences in the geological setting and the other environmental components. The Telecska Hills area is located at the southern margin of a dry alluvial fan of $10,000 \mathrm{~km}^{2}$ at that time. As a result, markedly thick dust sequences evolved in this area. Conversely, while the northern areas were characterized by a discontinuous permafrost and more scant vegetation, the southern areas of the basin experienced a sporadic permafrost and were covered by more lush vegetation. The rate of sedimentation experienced several drops during the Upper Würmian to $0.05-0.1 \mathrm{~mm} / \mathrm{yr}$ in the north and $0.1-0.2 \mathrm{~mm} / \mathrm{yr}$ in the south. Humus accumulation zones and immature paleosol horizons of several hundred years are observable only around 23,000 and 21,000 yr and around 18,000 and 16,000 yr. The composition of the mollusk fauna implies the emergence of milder climatic periods with more precipitation, resulting in the expansion of mixed taiga woodland mosaics during these periods in the basin (Sümegi and Krolopp 1996).

There is another increase in the rate of sedimentation from $16,000 \mathrm{yr}$ onwards, leading to the accumulation of dust sequences of considerable thickness up to $14,000-13,000 \mathrm{yr}$. The rate of dust accumulation was around $0.2-0.4 \mathrm{~mm} / \mathrm{yr}$ in the north and $0.3-0.5 \mathrm{~mm} / \mathrm{yr}$ in the south, with a gradually 
decreasing tendency. Finally, at around 11,000-12,000 yr, loess formation came to an end as the environmental prerequisites for loess formation disappeared.

\section{REFERENCES}

Ant H. 1963. Faunistische, ökologische und tiergeographische Untersuchungen zur Verbreitung der Landschnecken in Nordwestdeutschland. Abhandlungen des Landesmuseums für Naturkunde Münster 25:125. In German.

Boycott AE. 1934. The habitats of land Mollusca in Britain. Journal of Animal Ecology 22:1-38.

Bronk Ramsey C. 1995. Radiocarbon calibration and analysis of stratigraphy: the OxCal program. Radiocarbon 37(2):425-30.

Bronk Ramsey C. 2001. Development of the radiocarbon program. Radiocarbon 43(2A):355-63.

Frömming E. 1954. Biologie der Mitteleuropäischen Landgastropoden. Berlin: Deucher et Humboldt. 541 p. In German.

Grime JP, Blythe GM. 1969. An investigation of the relationships between snails and vegetation at the Winnats Pass. Journal of Ecology 57(1):45-66.

Hertelendi E, Csongor É, Záborszky L, Molnár J, Gál J, Gyốrffy M, Nagy S. 1989. A counter system for highprecision ${ }^{14} \mathrm{C}$ dating. Radiocarbon 31(3):399-406.

Hertelendi E, Sümegi P, Szöôr Gy. 1992. Geochronologic and paleoclimatic characterization of Quaternary sediments in the Great Hungarian Plain. Radiocarbon 34(3):833-9.

Hertelendi E, Kalicz N, Raczky P, Horváth F, Veres M, Svingor É, Futó I, Bartosiewicz L. 1996. Re-evaluation of the Neolithic in eastern Hungary based on calibrated radiocarbon dates. Radiocarbon 37(2):23941.

Horusitzky H. 1903. A diluviális mocsár löszrôl. Földtani Közlöny 33:209-16. In Hungarian.

Horváth A. 1954. A paksi pleisztocén üledékek csigái és értékelésük. Állattani Közlemények 44:171-88. In Hungarian.

Kerney MP, Cameron RAD, Jungbluth JH. 1983. Die Landschnecken Nord- und Mitteleuropas. HamburgBerlin: P Parey. 384 p. In German.

Krolopp E. 1961. A tihanyi felsố-pleisztocén Mollusca fauna. Földtani Intézet Évi Jelentése 1957-58-rôl: 505-9. In Hungarian.

Krolopp E. 1966. A Mecsek hegység környéki löszképzôdmények biosztratigráfiai vizsgálata. Földtani Intézet Évi Jelentése 1964-rôl:137-87. In Hungarian.

Krolopp E. 1967. A pleisztocén Mollusca fauna paleoökológiai vizsgálata. Ôslénytani Viták 8:1-4. In Hungarian.

Krolopp E. 1984. Verzeichnis der pleistozänen Mollusken Ungarns. Soosiana 10-11:75-8. In Hungarian.

Krolopp E, Sümegi P. 1990. Vorkommen von Vestia turgida (Rossmässler, 1836) in den pleistozänen Sedimenten Ungarns. Soosiana 18:5-10. In Hungarian.
Krolopp E, Sümegi P. 1991. Dominance level of the species Punctum pygmaeum (Draparnaud, 1801): a biostratigraphical and paleoecological key level for the Hungarian loess sediments of the Upper Würm. Soosiana 19:17-23.

Krolopp E, Sümegi P. 1992. A magyarországi löszök képzốdésének paleökológiai rekonstruckiója Mollusca fauna alapján. In: Szöôr Gy, editor. Fáciesanalitikai, Paleobiogeokémiai és Paleoökológiai Kutatások. Debrecen: MTA Debreceni Akadémiai Bizottság. p 247-63.

Krolopp E, Sümegi P, Hertelendi E, Kuti L, Kordos L. 1995. Szeged környéki löszképződmények keletkezésének paleoökológiai rekonstrukciója. Földtani Közlöny 125:309-61. In Hungarian.

Ložek V. 1964. Quartärmollusken der Tschechoslowakei. Prague: Rozpravy Ústredniho ústavu geologického 31. 374 p. In German.

Molnár B, Krolopp E. 1978. Latest Pleistocene geohistory of the Bácska loess area. Acta Minereologica et Petrographica [Szeged] 23:245-64.

Molnár B, Geiger J. 1995. Possibility for subdividing apparently homogeneous depositional sequences by combined use of sedimentological, palaeontological and mathematical methods. GeoJournal 36(2-3): 169-77.

Pécsi M. 1967. A löszfeltárások üledékeinek genetikai osztályozása a Kárpát-medencében. Földrajzi Értesitổ 16:1-19. In Hungarian.

Pécsi M. 1993. Negyedkor és löszkutatás. Budapest: Akadémiai Kiadó. 375 p. In Hungarian.

Preece RC. 1991. Accelerator and radiometric radiocarbon dates on a range of materials from colluvial deposits at Holywell Coombe, Folkstone. In: Lowe JJ, editor. Radiocarbon Dating: Recent Applications and Future Potential. Quaternary Proceedings 1. Cambridge: Quaternary Research Association. p 45-53.

Reimer PJ, Baillie MGL, Bard E, Bayliss A, Beck JW, Bertrand CJH, Blackwell PG, Buck CE, Burr GS, Cutler KB, Damon PE, Edwards RL, Fairbanks RG, Friedrich M, Guilderson TP, Hogg AG, Hughen KA, Kromer B, McCormac G, Manning S, Bronk Ramsey C, Reimer RW, Remmele S, Southon JR, Stuiver M, Talamo S, Taylor FW, van der Plicht J, Weyhenmeyer CE. 2004. IntCal04 terrestrial radiocarbon age calibration, 0-26 cal kyr BP. Radiocarbon 46(3):1029-58.

Rotarides M. 1931. A lösz csigafaunája, összevetve a mai faunával, különös tekintettel a szegedvidéki löszökre. A szegedi Alföldkutató Bizottság Könyvtára VI. Szakosztály. Állatttani Közlemények 8:1-180. In Hungarian.

Rotarides M. 1942. A szegedi és Szeged környéki artézi 
kutak kôzetanyagának pleisztocén puhatest faunája. Földtani Közlöny 72:52-63. In Hungarian.

Rousseau D-D, Puisségura J-J, Lautridou J-P. 1990. Biogeography of the Pleistocene pleniglacial malacofaunas in Europe. Stratigraphic and climatic implications. Palaeogeography, Palaeoclimatology, Palaeoecology 80(1):7-23.

Rudner ZE, Sümegi P. 2001. Recurring taiga foreststeppe habitats in the Carpathian Basin in the Upper Weichselian. Quaternary International 76-77:17789.

Soós L. 1943. A Kárpát-medence Mollusca Faunája. Budapest: Akadémiai Kiadó. 478 p. In Hungarian.

Sümegi P. 1989. Hajdúság felsô-pleisztocén fejlôdéstörténete finomrétegtani (üledékföldtani, ôslénytani, geokémiai) vizsgálatok alapján [PhD dissertation]. Debrecen: University of Debrecen. 96 p. In Hungarian.

Sümegi P. 1996. Az ÉK-magyarországi löszterületek összehasonlító ốskörnyezeti és sztratigráfiai értékelése [unpublished $\mathrm{PhD}$ dissertation]. Debrecen: University of Debrecen. 120 p. In Hungarian.

Sümegi P. 1998. Az utolsó 15000 év környezeti változásai és hatásuk az emberi kultúrákra Magyarországon. In: Ilon $\mathrm{G}$ editor. A régésztechnikusok kézikönyve. Savaria: Szombathely. p 367-97. In Hungarian.

Sümegi P. 1999. Reconstruction of flora, soil and landscape evolution, and human impact on the Bereg Plain from late glacial up to the present, based on palaeoecological analysis. In: Hamar J, Sárkány-Kiss A, editors. The Upper Tisa Valley. Szeged: Tiscia Monograph Se- ries. p 173-204.

Sümegi P. 2004. The results of paleoenvironmental reconstruction and comparative geoarchaeological analysis for the examined area. In: Sümegi P, Gulyás S, editors. The Geohistory of Bátorliget Marshland. Budapest: Archaeolingua Press. p 301-48.

Sümegi P. 2005. Loess and Upper Paleolithic Environment in Hungary. Budapest: Grafon Kiadó. 303 p.

Sümegi P, Krolopp E. 1996. A magyarországi Würm korú löszök képzôdésének paleoökológiai rekonstrukciója Mollusca fauna alapján. Földtani Közlöny 13:45-65. In Hungarian.

Sümegi P, Rudner ZE. 2001. In situ charcoal fragments as remains of natural wild fires of the upper Würm in the Carpathian Basin. Quaternary International 76-77: 165-76.

Sümegi P, Lóki J, Hertelendi E, Szöőr Gy. 1992. A tiszaalpári magaspart rétegsorának szedimentológiai és sztratigráfiai elemzése. Alföldi Tanulmányok 14: 75-87. In Hungarian.

Szöôr Gy, Balázs É, Cserháti Cs, Dinya L, Hertelendi E, Sümegi P, Szanyi J. 1992. Quarter és neogén Mollusca-héjak kemotaxonómiai és paleoökológiai elemzése. In: Szöór Gy, editor. Fáciesanalitikai, Paleobiogeokémiai és Paleoökológiai Kutatások. Debrecen: MTA Debreceni Bizottsága. p 111-81. In Hungarian.

Willis KJ, Rudner E, Sümegi P. 2000. The full-glacial forests of central and southeastern Europe. Quaternary Research 53(2):203-13. 